\title{
Czy analiza składnikowa jest metodą przestarzałą? Rozwój badań nad strukturą semantyczną jednostek leksykalnych we współczesnym językoznawstwie francuskim
}

Słowa klucze: sem, semem, analiza składnikowa, dyskurs, kontekst

\section{Uwagi wstępne}

Niniejszy szkic przedstawia w zarysie rozwój metody analizy składnikowej w strukturalnej semantyce francuskiej oraz omawia problemy jej współczesnych zastosowań $\mathrm{w}$ analizie jednostek leksykalnych, wypowiedzeń i tekstów. Stopniowe przejście od czysto teoretycznych koncepcji strukturalnych z połowy ubiegłego wieku (głównie teorie B. Pottiera i A. J. Greimasa) do znacznie szerszej, rozwijającej się do dziś interpretacyjnej semantyki tekstu (F. Rastier) jest związane z istotną ewolucją narzędzi badawczych, a także pola ich zastosowań. Pozwala to na odrębne potraktowanie tych dwóch ścieżek teoretyczno-metodologicznych, szczególnie w świetle tego, w jaki sposób starają się rozwiązywać problemy występujące nagminnie w praktycznej analizie materiału językowego. 


\section{Zarys rozwoju semantyki składnikowej we Francji}

Analiza składnikowa jest zwykle kojarzona przede wszystkim z metodologią badań nad znaczeniem wypracowaną w ramach lingwistyki strukturalnej, mimo że z pojęciem prostych cech semantycznych (w tradycji francuskiej noszących nazwę semów $\left.w^{1}\right)$ spotykamy się także w innych kontekstach, chociażby w modelach lingwistyki generatywnej (cf. teoria znaczników semantycznych, semantic marquers i semantic distinguishers Katza i Fodora 1963) czy w kognitywnej koncepcji prymitywów semantycznych (cf. Wierzbicka 1972, 1993). Niniejszy szkic dotyczy francuskiej semantyki składnikowej wywodzącej się z tradycji saussuriańskiej, według której język stanowi system, czyli zorganizowaną strukturę elementów powiązanych wzajemnymi relacjami (cf. de Saussure 1916, Sanders 1979). W tej perspektywie celem analizy językoznawczej jest wyodrębnienie i możliwie najbardziej wyczerpujący opis owych elementów, ich powiązań, zależności hierarchicznych oraz, w dalszej kolejności, mechanizmów ich funkcjonowania w kontekście. W wypadku semantyki składnikowej, opartej na modelach analizy fonologicznej, badanie struktury treści znaków językowych polega na rozłożeniu znaczeń na prostsze komponenty semantyczne, które jako takie mogą wchodzić w skład różnych jednostek leksykalnych.

Koncepcja wspomnianej metody analitycznej pochodzi w zasadzie z dwóch źródeł, uważanych w językoznawstwie za dwa przeciwstawne nurty teoretyczne. $Z$ jednej strony ma ona swe korzenie w strukturalizmie, wywodzi się bowiem z glossematyki duńskiego lingwisty L. Hjelmsleva (1943), który jako pierwszy wysunął tezę o izomorficzności planu wyrażenia i treści, postulując analizę tej ostatniej poprzez wydzielanie dystynktywnych cech semantycznych paralelnych do cech fonologicznych. Tą właśnie drogą poszła rozwijająca się szczególnie dynamicznie w latach 60. i 70. XX w. francuska semantyka strukturalna. Drugim źródłem analizy składnikowej są tezy semantyki generatywnej, która wprowadziła do opisu języka aparat pojęciowy logiki symbolicznej (głównie rachunek predykatów). W tym nurcie sytuują się prace J. J. Katza i J. A. Fodora na temat znaczników semantycznych

1 Sem, fr. sème lub trait sémantique (cecha semantyczna, ang. semantic feature). Z pewnymi zastrzeżeniami odpowiada saussuriańskiemu pojęciu elementu różnicujacego (élément différentiel, F. de Saussure 1916) oraz figury treści L. Hjelmsleva (figure du contenu, 1943). 
(1963), a także niemieckiego badacza M. Bierwischa na temat typów składników semantycznych i struktury semantycznej niemieckich przymiotników (1967). Główną myślą Bierwischa jest założenie, że w przeciwieństwie do tego, co ma miejsce w fonologii, znaczenia nie stanowią sumy swych składników, lecz hierarchiczne struktury posiadające wewnętrzną składnię, cechy semantyczne zaś są tu rozumiane jako predykaty odnoszące się do argumentów o określonych rolach ( $c f$. założenia gramatyki przypadków Fillmore’a 1968; Grzegorczykowa 1995).

Francuski termin sème został wprowadzony w roku 1957 przez badaczy, którzy opublikowali swoje prace w zbiorze zatytułowanym La notion de neutralisation dans la morphologie et dans la syntaxe (Pojęcie neutralizacji w morfologii i sktadni, [w:] Travaux de l'Institut de Linguistique, Faculté des Lettres de l'Université de Paris, $c f$. głównie artykuły B. Pottiera, I. Ivanova i G. Corréarda), następnie pojęcie to stosowali w sposób systematyczny B. Pottier w artykule z roku 1963 i A. J. Greimas w wydanej w 1966 pracy pt. Semantyka strukturalna (Sémantique structurale). Zaproponowana przez tych badaczy koncepcja analizy znaczenia jednostek leksykalnych (leksemów) oraz ich aktualizacji w dyskursie (sememów) rozwijała się dynamicznie w kolejnych latach (cf. m.in. Pottier 1974, 1980, 1992), znajdując bardzo interesującą kontynuację w semantyce interpretacyjnej François Rastiera (cf. Rastier 1987, 2001; Duteil-Mougel 2004).

W koncepcji Greimasa leksem, „względnie stała jednostka komunikacji”, jest definiowany jako „miejsce, w którym pojawiają się i spotykają semy wchodzące we wzajemne związki hierarchiczne" (1966: 38), natomiast semem to "efekt sensu” aktualizujący się dzięki użyciu leksemu w dyskursie. Wynika on z kombinacji jądra semicznego (noyau sémique, Ns), czyli względnie stałej zawartości leksemu, złożonej z ,hipotaktycznego układu semów” o funkcji „trwałego minimum semicznego" (Greimas 1966: 44), oraz semów kontekstowych (klasemów, classèmes, Cs), z których każdy stanowi „zmienną semiczną”, pozwalającą ,zdać sprawę ze zmian efektów sensu” (Greimas 1966: 45). Ten ogólny schemat struktury sememu $(\mathrm{Sm}=\mathrm{Ns}+\mathrm{Cs})$ prowadzi do opracowania pojęcia izotopii dyskursywnej, określanej najogólniej jako powtórzenie semów kontekstowych na osi syntagmatycznej dyskursu i zapewniającej spójność tekstu².

${ }^{2}$ Np. w zależności od kontekstu w zdaniu Ten pies znowu ujada zaktualizuje się izotopiczny klasem /zwierzęcy/ (sens dosłowny) lub /ludzki/ (sens przenośny, gdzie „ten 
Równolegle do badań Greimasa rozwija się analiza składnikowa Pottiera, który wykraczając poza perspektywę immanentnego strukturalizmu, szczególny nacisk kładzie na użycie języka w kontekście społecznym. Definiuje on sem jako „semantyczną cechę różnicującą sememu, określaną w odniesieniu do niewielkiego zbioru terminów, które użytkownik języka ma rzeczywiście do dyspozycji i których $\mathrm{z}$ dużym prawdopodobieństwem może użyć $\mathrm{w}$ danej okoliczności komunikacyjnej" (Pottier 1980: 169). Podstawową wytyczną dla identyfikacji semów jest zatem kontekst, w którym pewne leksemy mogą zostać użyte z mniejszym lub większym prawdopodobieństwem, inne natomiast, nawet jeśli są ich synonimami systemowymi, są z punktu widzenia tego użycia praktycznie wykluczone. Semem w koncepcji Pottiera składa się z dwóch typów semów: denotatywnych, które „w sposób stały i mocno ugruntowany społecznie określają znaczenie znaku", oraz konotatywnych, które ,charakteryzują to znaczenie w sposób niestały i często indywidualny” (Pottier 1974: 29). Semy denotatywne mogą być generyczne, „kiedy wskazują na przynależność sememu do ogólnej kategorii” (np. sem /człowiek/ w sememach 'mężczyzna', 'kobieta', 'chłopiec', 'dziewczynka'), albo specyficzne, „kiedy pozwalają odróżnić od siebie dwa sąsiednie sememy” (cf. Pottier 1974: 30 ; w powyższym przykładzie są to cechy semantyczne związane z płcią, czyli /męskość/ vs /żeńskość/, oraz z wiekiem, czyli /dorosłość/ vs /niedorosłość/). Natomiast semy konotatywne są nazywane inaczej wirtualnymi, gdyż mogą, ale nie muszą aktualizować się w dyskursie ${ }^{3}$.

W celu wyjaśnienia mechanizmów funkcjonowania sememów w kontekście, Pottier wprowadza pojęcia taksemu (taxème) i domeny doświadczenia (domaine d'expérience). Taksem to minimalna klasa semantyczna, która „składa się z szeregu znaków posiadających pewną ilość semów wspólnych, możliwych do użycia w danej sytuacji społeczno-kulturowej”, (Pottier 1974: 97); na przykład sememy 'obrazek', 'fotografia', 'rysunek', 'ilustracja', 'ry-

pies" pogardliwie odnosi się do człowieka). Efekt kompatybilności wszystkich elementów zdania wynika tu z faktu, że oba jądra semiczne mogą się łączyć z tym samym semem kontekstowym.

3 Niektóre wirtuemy mogą się aktualizować niezależnie od kontekstu (np. 'pizza' zawsze konotuje sem /włoskość/, gdyż jest to słowo żywcem wyjęte z języka włoskiego), dla innych natomiast kontekst jest absolutnie niezbędny. W tym wypadku Pottier mówi o konotacji kontekstowej; na przykład w wypowiedzeniu Zeszłej nocy muzeum odwiedzili złodzieje, semem 'odwiedzili' zawiera konotujący sem kontekstowy /w celu kradzieży/, który nie pojawia się w typowych użyciach leksemu odwiedzić. 
cina', 'reprodukcja', 'plansza', 'mapa' należą do jednego taksemu //nie-tekst w książce//. Natomiast domena doświadczenia to klasa semantyczna o wyższym stopniu ogólności, która może ogarniać wiele taksemów, gdyż ,pokrywa szeroką strefę tematyczną, związaną z doświadczeniem całej grupy społecznej” (Pottier 1974: 97) i zapewnia semantyczną izotopię tekstu. Na przykład semem 'papier' może być kontekstowo przypisany do różnych domen; w wypowiedzeniu Pańskie papiery, proszę! będzie on przypisany do domeny //policja//, a w syntagmie papier do pakowania wejdzie w domenę //handel//.

Interpretacyjna semantyka tekstu Rastiera stanowi swoistą kontynuację badań Pottiera, skupiając się nie tyle na analizie znaczenia leksemów poza kontekstem lub w kontekstach najbardziej typowych, lecz na opisie sensu, jaki powstaje $\mathrm{w}$ obrębie całych tekstów z uwzględnieniem szerokiego kontekstu (obejmującego całość badanego tekstu, intertekst oraz czynnik gatunkowy). Rastierowski semem różni się w pewnych punktach od sememu Pottiera, szczególnie w kwestii wirtualnych (czyli kontekstowych) cech semantycznych. Jest on definiowany najogólniej jako treść morfemu (czyli minimalnego znaku językowego) i stanowi kombinację semów generycznych i specyficznych, inherentnych i / lub aferentnych ${ }^{4}$ (Rastier 1987: 53). Semy są określane w oparciu o przynależność tworzonych przez nie sememów do danego takse$m u$ (,minimalna w języku klasa sememów, w obrębie której są definiowane ich semantemy oraz ich wspólny sem mikrogeneryczny", Rastier 1987: 276) i służą do ustanowienia wzajemnych opozycji między tymi sememami, czyli pełnią funkcję różnicująca.

W wypadku podziału na semy generyczne i specyficzne koncepcja Rastiera zbiega się w pełni z tym, co proponuje w tej materii autor tych pojęć, Pottier (1964): ,semem generycznym nazywamy właściwość, która jest charakterystyczna dla wszystkich elementów badanego zbioru, a semem specyficznym właściwość, która jest charakterystyczna tylko dla jednego elementu tego zbioru" (Rastier 1987: 54).

Drugie rozróżnienie (sem inherentny $v s$ sem aferentny) to najbardziej oryginalny i twórczy wkład Rastiera w koncepcję mikrostruktury sememu. Sem inherentny, „biegun symetrycznej relacji między dwoma sememami należącymi do tego samego taksemu", stanowi semantyczną cechę definicyjna

4 Ponieważ nie ma tradycji tłumaczenia tych dwóch ostatnich nazw na język polski, używamy spolszczonej formy francuskich słów inhérent (przyrodzony, nierozłącznie związany, właściwy czemuś) i afférent (napływający z zewnątrz, naddany). 
sememu, podczas gdy sem aferentny (wirtuem ${ }^{5}$ ), definiowany jako „,biegun anty-symetrycznej relacji między dwoma sememami należącymi do różnych taksemów" (Rastier 1987: 275), jest cechą dodatkową, nieobecną w typowym użyciu sememu, aktualizowaną wyłącznie w kontekście. Nawiązując do przytoczonego wyżej przykładu, w sememach 'mężczyzna' i 'kobieta', należących do tego samego takiemu, cechy semantyczne /męskość/ vs /żeńskość/ stanowią ich semy inherentne, gdyż wchodzą w sposób konieczny w definicje odpowiadających im leksemów i pozwalają na ustanowienie między nimi opozycji (według kryterium płci). Dzięki operacji semantycznej zwanej aferencja (afférence), czyli ,inferencji prowadzącej do aktualizacji semu aferentnego" (Rastier 1987: 273), kontekst może uzupełnić ostateczną konfigurację sememu o semy aferentne, które normalnie wchodzą w skład sememów należących do innego taksemu. Na przykład, sememom 'mężczyzna' i 'kobieta' można przypisać w kontekście odpowiednio cechy semantyczne /siła/ vs /słabość/ (w świetle powszechnej opinii, że mężczyzna jest lub powinien być silny, kobieta zaś to istota słaba), przy czym są to semy niestałe, zależne od kontekstu i zapożyczone z innego taksemu (//natężenie mocy//), czyli właśnie semy aferentne ${ }^{6}$.

Identyfikacja różnicujących semów generycznych i specyficznych nie opiera się jednak wyłącznie na relacjach, jakie zachodzą między elementami minimalnej klasy sememów, taksem bowiem stanowi zbiór zaledwie z poziomu mikrogenerycznego, a istnieją jeszcze dwa wyższe poziomy: poziom domeny semantycznej (czyli poziom mezogeneryczny) i poziom wymiaru semantycznego (czyli poziom makrogeneryczny). Na przykład sememy 'nóż', 'widelec', 'łyżka' należą do taksemu //sztućce//, do domeny //żywienie// i wymiaru //nieożywiony//. W tej perspektywie możliwe jest zdefiniowanie semów generycznych według rosnącego stopnia ich ogólności, to znaczy semów mikrogenerycznych, mezogenerycznych i makrogenerycznych ze względu na to, czy wskazują na przynależność sememu do taksemu, domeny czy wymiaru semantycznego, podczas gdy semy specyficzne występują wy-

5 Przypomnijmy, że u Pottiera termin wirtuem oznacza całą klasę wirtualnych cech semantycznych sememu.

${ }^{6}$ Ten niestały, niejako przygodny charakter semów aferentnych nie oznacza jednak, że semy te nie są cechami różnicującymi, przeciwnie, są nimi na tej samej zasadzie co semy inherentne, a w konkretnym kontekście ich aktualizacja może być bardzo istotna, czasami wręcz kluczowa dla zrozumienia treści przekazu. 
łącznie na poziomie taksemu i służą do rozróżniania między sobą sememów powiązanych wspólnym semem mikrogenerycznym.

Tak rozumiana koncepcja sememu pozwala na zwiększenie zasięgu systematycznej analizy i uchwycenie nawet najlżejszych niuansów sensu, nie tylko w kontekście wypowiedzenia, ale również na przestrzeni całego tekstu. Rastier kładzie tu nacisk na perspektywę odbiorcy, podmiotu interpretującego (stąd nazwa „semantyka interpretacyjna”), który poprzez zastosowanie odpowiednich operacji interpretacyjnych, mających na celu identyfikację relewantnych elementów sensu i przypisanie sememów do konkretnych klas semantycznych, nie tylko odkodowuje, ale wręcz, do pewnego stopnia, tworzy sens przekazywanego mu wypowiedzenia czy tekstu.

\section{Słabe strony analizy składnikowej jako metody badań semantycz- nych}

Analiza składnikowa, sześćdziesiąt lat temu bardzo nowatorska, należy dziś właściwie do najstarszych metod badań nad znaczeniem leksykalnym. Czy oznacza to jednak zarazem, że jest metodą przestarzałą? Niewątpliwie przyznać należy, że szczególnie jej francuska wersja z lat 60., nie biorąca w wystarczający sposób pod uwagę kontekstowych relacji między poszczególnymi elementami sensu, zasługuje na krytykę i nadaje się dziś właściwie głównie do celów dydaktycznych w warunkach uniwersyteckich. Nie ulega wątpliwości, że zarzuty, jakie można postawić tej metodzie, są istotne z punktu widzenia współczesnego podejścia do badań semantycznych, coraz dobitniej uwzględniającego szeroko pojęty kontekst (bez względu na to, czy nazwiemy go dyskursem, tekstem czy wymiarem parole) i wyraźnie negującego immanentny strukturalizm w analizie znaczeń leksykalnych. Zarzuty te są związane przede wszystkim z trudnościami, jakie tradycyjna analiza składnikowa napotyka w kwestii metodycznego wyodrębniania i leksykalizacji minimalnych cech semantycznych, a które wynikają nie tylko z niedopracowania narzędzi metodologicznych (izomorfizm między planem wyrażenia i planem treści jest tylko częściowy, co wyklucza automatyczne przeniesienie na teren semantyki metod analizy fonologicznej), ale również z szerzej pojętych problemów opisu językoznawczego za pomocą metajęzyka oraz doboru relewantnych kryteriów analizy. Pytania, które narzucają się w tym kontekście, są jednocześnie proste i kłopotliwe: 
- czym jest minimalna cecha semantyczna (sem)?

- jaką ilość semów należy brać pod uwagę w analizie składnikowej znaczenia leksykalnego?

- czy badanie znaczeń poza kontekstem jest podejściem językoznawczo poprawnym?

- według jakich kryteriów dokonywać wyodrębniania semów w danym kontekście?

- czy i w jaki sposób należy ustalić ich wzajemne relacje hierarchiczne?

- jak zapewnić ich poprawną leksykalizację?

W szczególności dwa pierwsze pytania, dotyczące natury oraz ilości semów, są podstawą licznych dyskusji językoznawców ( $c f$. np. Rastier 1987: 18-33); przyznać trzeba, że definicja minimalnej cechy semantycznej nie jest jednoznaczna i zależy od przyjętej przez danego badacza perspektywy. W nurcie strukturalnym sem jest określany najogólniej jako minimalna jednostka substancji treści (według terminologii Hjelmsleva 1943), jednak już koncepcja jego bardziej szczegółowej natury budzi polemiki: minimalna cecha semantyczna może być definiowana jako przymiot danego referenta lub część składowa danego konceptu, czy też jako powszechnik (niezmiennik) semantyczny, stanowiący jednostkę niezależną od swej leksykalizacji w danym języku. Również problem ilości semów nie został rozwiązany w sposób ostateczny. O ile niektórzy badacze proponują listę od kilkunastu do kilkudziesięciu cech semantycznych, które, ich zdaniem, pozwalają na skuteczne rozróżnienie między sobą wszystkich słów w języku (np. Wierzbicka 1972: 16), o tyle inni obawiają się, że ilość semów potrzebnych do takiego rozróżnienia jest nieskończona, a przynajmniej nie mniejsza niż ilość owych rozróżnianych słów (np. Eco 1976: 50). Jeżeli zdołamy - w sztuczny sposób - uniknąć tej polemiki, definiując pojęcie minimalnej cechy semantycznej w ramach konkretnej optyki badawczej, pozostają wciąż inne problemy, natury bądź teoretycznej (czy analiza składnikowa ma służyć badaniu znaczeń poza kontekstem czy konkretnego sensu wytworzonego w dyskursie), bądź metodologicznej (jakie narzędzia dobrać do każdej z tych perspektyw, jakie poziomy analizy wyodrębnić, jakie kryteria przyjąć, jak uniknąć przypadkowości i niesystematyczności w wyodrębnianiu semów, jak udowodnić ich relewantność). Nie mniej ważną kwestią jest problem leksykalizacji semów, związany z jedną z większych bolączek językoznawstwa, jaką jest konieczność zastosowania języka do opisu jego samego; na tym planie niezbędne jest 
dokonanie teoretycznie i metodologicznie poprawnego rozróżnienia między poziomem leksematycznym i poziomem semicznym przy konieczności użycia identycznych środków (meta)językowych, a także uwzględnienie kwestii istnienia „pustych pól” leksykalnych.

Nie ulega zatem wątpliwości, że tak liczne trudności w jednoznacznym rozwikłaniu podstawowych problemów metodologicznych mogą negatywnie wpłynąć na spójny obraz analizy składnikowej jako naukowej metody badania znaczeń leksykalnych. To jednak nie oznacza, że należy ją tym samym uznać za wyczerpaną i odrzucić, poszukując metod bardziej adekwatnych; przeciwnie, odpowiednie wykorzystanie jej założeń w obrębie rozwijających się współcześnie teorii semantycznych może nadać jej nowy wymiar i wyeksponować tkwiący w niej niezaprzeczalny potencjał opisowy.

\section{Zalety analizy składnikowej i możliwości jej zastosowań we współ- czesnych badaniach nad dyskursem}

W jaką stronę powinno zatem pójść badanie semantyczne realizowane za pomocą analizy składnikowej, tak aby w jak największym stopniu wykorzystać teoretyczne możliwości tej metody? Widzimy dziś wyraźnie, że leżąca u jej podstaw teza o izomorficzności planu wyrażenia i treści, zakładająca możliwość rozłożenia znaczenia jednostki leksykalnej na czynniki pierwsze według zasad przejętych $\mathrm{z}$ analizy fonologicznej, nie sprawdziła się w praktyce; wynika to z rozdźwięku między ścisłymi założeniami strukturalizmu co do systemowej natury języka a możliwościami badania jego najsłabiej ustrukturyzowanej części, jaką jest słownictwo ${ }^{7}$, chociażby z uwagi na wymienione wyżej trudności teoretyczno-metodologiczne. Jednakże paradoksalnie pójście o krok dalej w stronę jeszcze mniej systematycznego wymiaru języka, jakim jest jego użycie w konkretnej sytuacji, pozwala na bardzo skuteczne zastosowanie analizy składnikowej jako metody badań semantycznych.

Opisana wyżej koncepcja Rastiera, wywodząca się z klasycznej analizy struktury znaczenia i wykorzystująca tradycyjne pojęcia leksemu, semu, seтети, klasemu, izotopii, stanowi bardzo zaawansowaną propozycję metodo-

7 Dotyczy to zarówno badań leksykologicznych, jak i definicji leksykograficznych. Przy tworzeniu tych ostatnich można, rzecz jasna, posłużyć się analizą semiczną, jednak nie można identyfikować poszczególnych elementów definicji słownikowej z minimalną cechą semantyczną (semem), gdyż są to jednostki odrębnej natury, określone w drodze zupełnie innej procedury metodologicznej (cf. Mel’čuk et al. 1981, Rastier 1987: 30). 
logiczną, otwierającą szerokie możliwości nie tylko przed precyzyjną analizą słownictwa (zawsze w odniesieniu do kontekstu użycia), ale również przed badaniem skomplikowanego, wielopoziomowego zjawiska, jakim jest sens w tekście. Dynamiczny charakter sensu, jaki wynika z użycia leksemów w danym kontekście, zakłada wzięcie pod uwage przez odbiorcę tylko relewantnych elementów treści przy jednoczesnej wirtualizacji tych cech semantycznych, które, choć stanowią część słownikowej definicji leksemu, są cechami tylko „względnie stałymi” (cf. Greimas 1966: 44). Z drugiej strony, w olbrzymim stopniu na ostateczny sens wypowiedzeń i tekstów wpływa kontekstowo wymuszone przechodzenie sememów z jednej klasy semantycznej do innej (mechanizm aferencji), zjawisko bardzo dokładnie i systematycznie opisane przez Rastiera właśnie przy zastosowaniu udoskonalonej wersji semantyki składnikowej.

Kluczem do rozwoju metody wydaje się więc maksymalne ukontekstowienie leksemów, czyli wyjście poza abstrakcyjne pojęcie „systemu” w sensie saussuriańskim, pojęcie rozumiane często w sposób zbyt sztywny i okrojony, a przez to wypaczający w dużym stopniu założenia myśli strukturalnej. W teorii Rastiera wpływ kontekstu, dokonujący się na różnych poziomach (tekstu, intertekstu, praktyki dyskursu), określa charakter i rozmaite związki jednostek sensu na planie mikrostruktury sememów. Pozwala to na precyzyjne zdefiniowanie wzajemnych relacji między elementami z poziomu mikrosemantycznego (semy relewantne dla danego użycia leksemu) i makrosemantycznego (sens całego tekstu wynikający z zastosowania skomplikowanych operacji interpretacyjnych).

Analiza składnikowa biorąca pod uwagę szeroko pojęty kontekst oraz jego wpływ na mikrostrukturę sememów użytych w danym wypowiedzeniu lub tekście pozwala zatem na systematyczny opis różnorodnych zjawisk dyskursywnych, takich jak:

1) problem spójności semantycznej tekstu, mianowicie wyodrębnianie i hierarchizacja izotopii oraz zasady przewidywalności aktualizacji izotopicznych elementów sensu w perspektywie interpretacyjnej (z punktu widzenia odbiorcy);

2) semantyczny mechanizm powstawania i względnie jednoznacznej interpretacji sensów przenośnych, tropicznych, zjawiska polisemii, bliskoznaczności i opozycji dyskursywnej poprzez analizę kontekstowo 
uwarunkowanej przynależności sememów do odpowiednich klas semantycznych;

3) kwestia zabarwienia emocjonalnego i/lub wartościowania sememu, wypowiedzenia lub tekstu (izotopie ewaluacyjne);

4) wpływ intertekstu i kontekstu gatunkowego na sens analizowanej sekwencji (precyzyjna lokalizacja elementów treści będących nośnikami informacji intertekstualnych i gatunkowych), itp.

W tym zastosowaniu metoda analizy składnikowej nabiera nowego wymiaru, przestaje być niedoskonałą kalką analizy fonologicznej, lecz dostosowana do nieskończenie bardziej skomplikowanego przedmiotu badań, jakim jest signifié w relacji do signifiant, pozwala na wykroczenie poza system w kierunku parole, pozostając jednak nadal w obrębie szeroko i twórczo pojętych ram strukturalizmu.

\section{Bibliografia}

Bierwisch M., 1967, Some Semantic Universals of German Adjectivals, Foundations of Language 3, s. 1-36.

DuteiL-Mougel C., 2004, Référence et textualité: le point de vue de la sémantique interprétative, [online], http://www.revue-texto.net/Reperes/Reperes.html [23.01.2009].

Eco U., 1976, Peirce and contemporary semantics, Versus 15, s. 49-65.

Fillmore Ch. J., 1968, The Case for Case, w: Bach E. and Harms T. (red.), Universals in Linguistic Theory, New York: Holt, Rinehart and Winston, s. 1-88.

Greimas A. J., 1966, Sémantique structurale, Paris: Larousse.

Grzegorczýowa R., 1995, Wprowadzenie do semantyki językoznawczej, Warszawa: Wydawnictwo Naukowe PWN.

Huelmslev L., 1943, tł. fr. 1969, Prolégomènes à une théorie du langage, Paris: Minuit.

Katz J. J., Fodor J. A., 1963, Structure of a semantic theory, Language 39, s. 170-210.

MeL'Čú I. A., Iordanskaja L. N., Arbatchewsky-Jumarie N., 1981, Un nouveau type de dictionnaire: le dictionnaire explicatif et combinatoire du français contemporain, Cahiers de lexicologie 38-1, s. 3-34.

PоттіER B., 1963, Recherches sur l'analyse sémantique en linguistique et en traduction mécanique, Nancy: Université de Nancy.

PotTier B., 1964, Vers une sémantique moderne, w: Travaux de linguistique et de littérature, s. 107-138.

PоттіеR B., 1974, Linguistique générale. Théorie et description, Paris: Klincksieck. 
PotTier B., 1980, Sémantique et noémique, w: Annuario de Estudios Filológicos, Cáceres: Universidad de Extremadura, s. 169-177.

PotTier B., 1992, Sémantique générale, Paris: PUF.

RASTIER F., 1987, Sémantique interprétative, Paris: PUF.

Rastier F., 2001, Arts et sciences du texte, Paris: PUF.

SAnders C., 1979, «Cours de linguistique générale» de Saussure, Paris: Hachette.

Saussure F. de, 1916, wyd. kryt. 1972, Cours de linguistique générale, Paris.

Wierzbicka A., 1972, Semantic primitives, Francfort: Athenäum.

WierzBICKA A., 1993, La quête des primitifs sémantiques: 1965-1992, Langue française 98 , s. 9-23.

\section{L'analyse componentielle est-elle une méthode dépassée? Le développement de la recherche sur la structure sémantique des unités lexicales dans la linguistique française contemporaine}

\section{(rés u mé)}

L'objectif de l'article est double. D'une part, il s'agit de présenter un bref aperçu du développement de la sémantique componentielle au sein du structuralisme français, à partir des années 1960 jusqu'au début du XXI ${ }^{\text {ème }}$ siècle, en considérant comme essentiels les travaux de A. J. Greimas, de B. Pottier et de F. Rastier. D'autre part, nous abordons succinctement le problême de l'analyse componentielle, méthode abandonnée souvent comme dépassée, pour considérer ses avantages, ses désavantages et les possibilités de son application à la recherche sur le discours. En fait, l'analyse componentielle de lexèmes peut s'averer peu rentable si l'on considère ceux-ci en dehors du contexte ou seulement dans leurs contextes typiques. Par contre, leur contextualisation maximale, incluant l'impact des facteurs macro-sémantiques (intertexte, dimension générique, etc.) sur la micro-structure du sens créé et interprété, ouvre devant cette méthodologie de nouvelles perspectives et en fait un outil efficace pour une analyse du sens en discours. 